\title{
COMMUNICATION STYLES AND MULTIPLE INTELLIGENCES TOWARD DIFFERENTIATED INSTRUCTION
}

\author{
"Vanessa Joy Z. Judith
}

\section{Abstract}

This study determined the Communication Styles and the dominant Multiple Intelligence of Education students of educational services of Carlos Hilado Memorial State College for Academic Year 2017 -2018.Specifically when taken as a whole and grouped according to year level and sex, difference in the communication styles when grouped according to year, sex and Multiple Intelligences and relationship between type communication styles and multiple intelligences. The participants of this study were the second year to fourth students in the College of Education for Academic Year 20172018.The Communication Styles and Multiple Intelligences Descriptive Questionnaires were utilized. Means, Standard Deviation, One- Way ANOVA and Pearsons' $r$ were used. The study revealed that:(1) The dominant communication styles of the College of Education students when taken as a whole and grouped according to year level and was Pragmatist, (2) the dominant multiple intelligence possessed by the College of Education students when taken as a whole was Interpersonal. According to year level, second year was interpersonal, third year was logical, and fourth year was intrapersonal. As to sex, both male and female possessed intrapersonal intelligence, (3)no significant difference that exists between communication styles and personal variables, and (4)No significant difference that exists between multiple intelligences and personal variables.

Keywords: Communication Styles, Multiple Intelligences, Differentiated Instruction.

\section{Introduction}

The school is the institution where children acquire skills, abilities, and knowledge in different fields; they develop and shape their personality through the activity of learning.Success in the learning process depends on varied factors. However, much can be attributed to the communication process as vital to effective learning as it is in all areas of life where it is used to persuade, to influence relationships, to inform, to share, to discover and uncover information (Weaver, 2001). How sensitive the teacher is to the communication process that happens in the classroom can spell the outcome of learning (Fashiku, 2017). Classroom instruction that produces positive results acknowledges the need for a liberal use of nonverbal cues, student involvement and team communication. Whether by means of direct or indirect communication, instructors must convey instruction to students within a classroom. When lecturing or describing assignments, a teacher must gauge the comfort level of each of his students with his communication style (Silver, 2018). Student involvement during classroom discussions typically fosters a healthy communication process. Students should be coaxed to participate in the classroom, despite the fact that many students are reticent to voice their opinions. The solicitation of participation serves multiple purposes. Students observe that their questions are worthy of being answered, can freely exchange ideas with one another and can build confidence as they express themselves in public. How students communicate their approach to learning need to be considered also in the learning process that happens in the classroom whether they communicate as "Activists", "Reflectors", "Theorists" or "Pragmatists" (Honey, 2000).

Moreover, Howard Gardner's work on Multiple Intelligence has influenced the way many teachers approach their classroom instruction (Gardner, 1993). There are many ways to demonstrate understanding and it is important to incorporate these intelligences when planning to ensure inclusion for all students, and for students to receive the best possible learning experience. With an understanding of Gardner's theory of multiple intelligences teachers can promote new possibilities for learning, with greater emphasis on lifelong learning, which support the development of students' skills in creativity and innovation.

*Faculty - College of Education, Carlos Hilado Memorial State College-Talisay City, Negros Occidental, Philippines 
Different teaching and learning strategies can accommodate students with these different ability levels, including those who do not learn in traditional ways. Empowering students to learn through multiple modalities fosters a collaborative classroom where students are comfortable experimenting and letting others experiment (Borek 2003). Multiple intelligences can allow students to safely explore and learn in many ways, and they can help students direct their own learning.

By understanding not only that there are different intelligences, but also how to teach to them, teachers can effectively implement lessons in a way that allows all learners to show what they know, not just those who read and write well.

It is in this light that the researcher necessitate to conduct a study on communication styles and multiple intelligences as basis for an individualized learning instruction.

\section{Statement of the Problem}

The purpose of the study is to determine the Communication Styles and Multiples Intelligences as Basis for teaching and learning materials of the students in the College of Education in Carlos Hilado Memorial State College for Academic Year $2017-2018$.

Specifically, it seeks to answer the following:

1. What is the communication style of the College of Education students when taken as a whole and grouped according to year level and sex?

2. What is the type of multiple intelligences of the students as ranked when taken as a whole and grouped according to year level and sex?

3. Is there a significant difference in the communication styles when grouped according to year level,sex and Multiple Intelligences?

4. Is there a significant relationship between type communication styles and multiple intelligences?

5. Based on the findings, what teaching and learning materials can be formulated?

\section{Conceptual Framework}

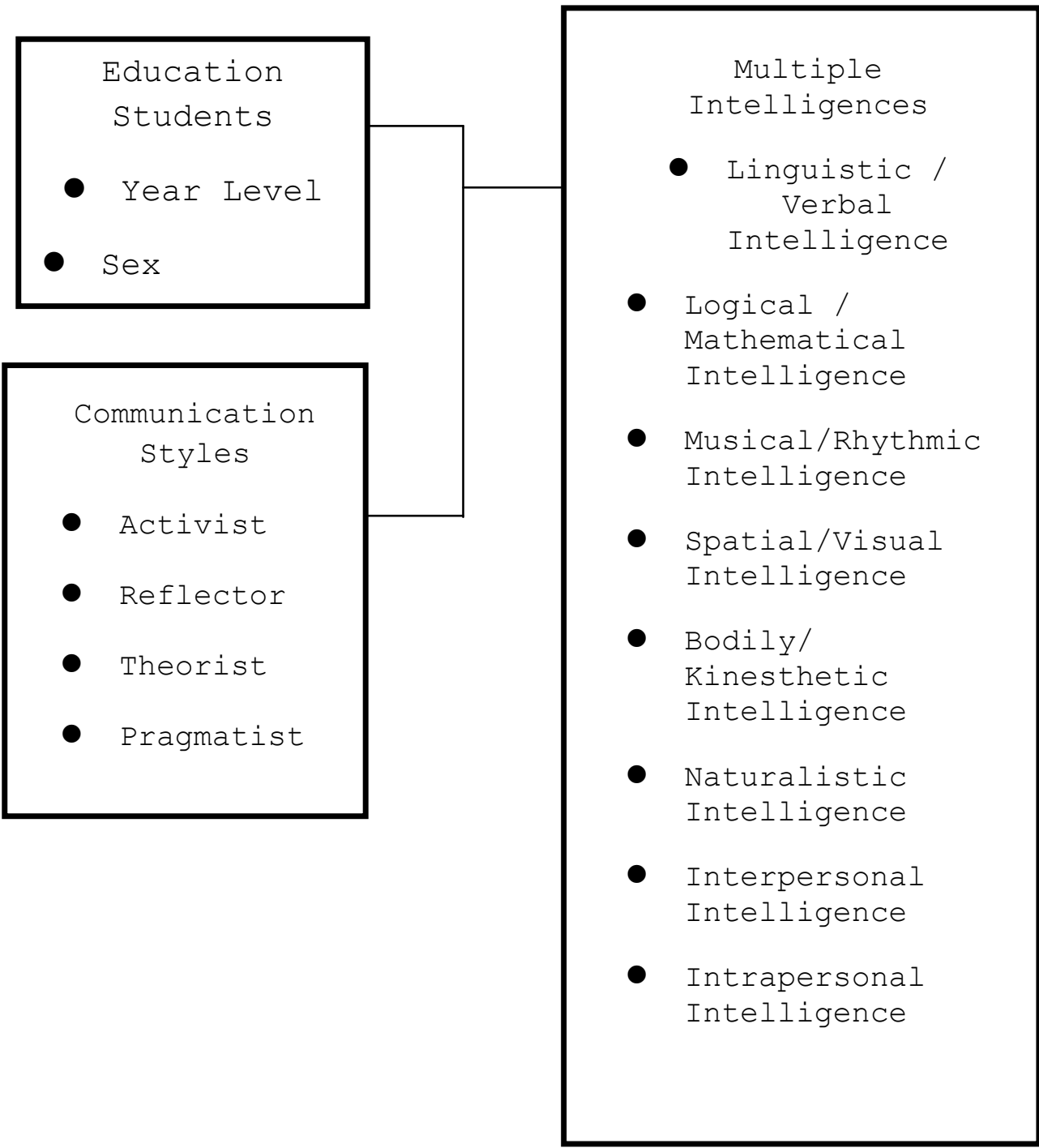




\section{Scope and the Limitation of the Study}

This study is limited itself in determining the Communication Styles and Multiple Intelligence as basis for teaching and learning materials of the Bachelor of Secondary Education students in the College of Education in Carlos Hilado Memorial State College- Talisay Campus for AY 2017-2018.

\section{Method of Research Used}

The descriptive method of research was used in this study. Stratified cluster sampling was employed in the selection of the participants.

\section{Respondents of the Study}

The participants of this study were the Second to Fourthe year Bachelor of Secondary Education students in the College of Education for Academic Year 2016- 2017.

\section{Research Instrument Used}

The questionnaire used in this study were modified questionnaires.

To establish the validity of the instruments, a panel of five jurors who are experts in this field wererequested to validate the content of the questionnaire. This was evaluated using the criteria developed for the evaluation of survey questionnaires set forth by Carter V. Good and Douglas B. Scates. The final draft of the questionnaire was prepared after considering the juror's corrections and suggestions for improvement.

The statistical tool used to determine the reliability and the interval consistency of the instrument was the alpha coefficient known as Cronbach Alpha.

The means and standard deviation were employed as descriptive statistics while $\mathrm{t}$ - test for the independent samples, One- Way Analysis of Variance and Pearson Product Moment Coefficient of correlations was used as inferential statistics.

\section{Results and Discussion}

Table 1 shows the dominant communication style of the College of Education students when taken as a whole and grouped according to year level and sex

\section{Table 1}

The Dominant Communication Style of Education Students when taken as a whole and grouped according to year level and sex

\begin{tabular}{|c|c|c|c|}
\hline Communication Styles & $\mathrm{M}$ & $\mathrm{SD}$ & Rank \\
\hline \multicolumn{4}{|l|}{ A. As a Whole } \\
\hline Activist & 3.98 & .50 & 3 \\
\hline Reflector & 3.99 & .46 & 2 \\
\hline Theorist & 3.94 & .46 & 4 \\
\hline Pragmatist & 4.21 & .37 & 1 \\
\hline \multicolumn{4}{|l|}{ B. Year Level } \\
\hline \multicolumn{4}{|l|}{ Second Year } \\
\hline Pragmatist & 4.20 & .34 & 1 \\
\hline Activist & 3.95 & .43 & 2 \\
\hline Reflector & 3.94 & .44 & 3 \\
\hline Theorist & 3.91 & .39 & 4 \\
\hline \multicolumn{4}{|l|}{ Third Year } \\
\hline Pragmatist & 4.22 & .36 & 1 \\
\hline Reflector & 4.02 & .46 & 2 \\
\hline Activist & 4.00 & .50 & 3 \\
\hline Theorist & 3.95 & .47 & 4 \\
\hline \multicolumn{4}{|l|}{ Fourth Year } \\
\hline Pragmatist & 4.20 & .39 & 1 \\
\hline Reflector & 3.99 & .48 & 3 \\
\hline Activist & 4.00 & .53 & 2 \\
\hline Theorist & 3.94 & .50 & 4 \\
\hline \multicolumn{4}{|l|}{ C. Sex } \\
\hline \multicolumn{4}{|l|}{ Male } \\
\hline Pragmatist & 4.23 & .41 & 1 \\
\hline Reflector & 4.06 & .49 & 2.5 \\
\hline Activist & 4.06 & .54 & 2.5 \\
\hline Theorist & 3.97 & .50 & 4 \\
\hline
\end{tabular}




\begin{tabular}{llll}
\hline Female & & & \\
Pragmatist & 4.19 & .33 & 1 \\
Reflector & 3.95 & .44 & 2 \\
Activist & 3.93 & .47 & 3 \\
Theorist & 3.92 & .44 & 4 \\
\hline
\end{tabular}

Table 1 shows the dominant communication styles of Education students when taken as a whole and grouped according to year level and sex. Student's most dominant type is Pragmatist $(\mathrm{M}=4.21$, $\mathrm{SD}=.37)$, followed by Reflector $(\mathrm{M}=4.00, \mathrm{SD}=.47)$, then Activist $(\mathrm{M}=3.99, \mathrm{SD}=.50)$ and Theorist $(\mathrm{M}=3.94, \mathrm{SD}=.46)$.

The dominant communication style of students when grouped according to year level. For $2^{\text {nd }}$ year students, their most dominant is Pragmatist $(\mathrm{M}=4.20, \mathrm{SD}=.34)$ and their least is Theorist $(\mathrm{M}=3.91, \mathrm{SD}=.38)$. For the $3^{\text {rd }}$ year students, their most dominant communication style is Pragmatist $(\mathrm{M}=4.22, \mathrm{SD}=.36)$ and their least dominant type is Theorist $(\mathrm{M}=3.95, \mathrm{SD}=.47)$. For the $4^{\text {th }}$ year education students, their most dominant communication type is Pragmatist ( $M=4.21$, $\mathrm{SD}=.39$ ) and their least dominant type is Theorist $(\mathrm{M}=3.94, \mathrm{SD}=.50)$.

The dominant communication style of education students when grouped according to sex. The most dominant communication styles of male is Pragmatist $(\mathrm{M}=4.24, \quad \mathrm{SD}=.41)$, followed by Reflector $(\mathrm{M}=4.07, \mathrm{SD}=.49)$, then Activist $(\mathrm{M}=4.06, \mathrm{SD}=.54)$ and their least dominant communication style is Theorist $(\mathrm{M}=3.97$, $\mathrm{SD}=.50)$. For females, their most dominant communication style is Pragmatist $(\mathrm{M}=4.20$, $\mathrm{SD}=.33)$, followed by Reflector $(\mathrm{M}=3.95, \mathrm{SD}=.44)$, then Activist $(\mathrm{M}=3.92, \mathrm{SD}=.47)$ and the least is Theorist $(\mathrm{M}=3.92, \mathrm{SD}=.44)$.

Pragmatists are keen on trying out ideas, theories and techniques to see if they work in practice. They positively search out new ideas and take the first opportunity to experiment with applications (Roswell, J.).

They are the sort of people who return from courses brimming with new ideas that they want to try out in practice. They like to get on with the things and act quickly and confidently on ideas that attract them.

They tend to be impatient with ruminating and open-ended discussions. They are essentially practical, down-to-earth people who like making practical decisions and solving problems. They responds to problems and opportunities as 'a challenge'. their philosophy is: "There is always a better way" and "If it works, it's good". They want to know how to apply what they are learning in the real world. And interested in what works, what gives results.

Table 2 shows the dominant multiple intelligences of the College of Education students when taken as a whole and grouped according to year level and sex

\section{Table 2}

\section{The Dominant Multiple Intelligences of Education Students when taken as a wholeand grouped according to year level and sex}

\begin{tabular}{lccc}
\hline Multiple Intelligence & M & SD & Rank \\
\hline A. As a Whole & & & \\
Interpersonal & 4.07 & .47 & 1 \\
Logical & 4.04 & .53 & 2 \\
Musical & 4.03 & .52 & 3 \\
Linguistic & 3.94 & .52 & 4 \\
Intrapersonal & 3.92 & .50 & 5 \\
Spatial & 3.84 & .45 & 6.5 \\
Bodily & 3.84 & .51 & 6.5 \\
B. Year Level & & & \\
Second Year & & & \\
Interpersonal & 4.09 & .58 & 1 \\
Musical & 3.98 & .60 & 2 \\
Intrapersonal & 3.94 & .62 & 3 \\
Bodily & 3.73 & .59 & 4 \\
Logical & 3.72 & .62 & 5 \\
Spatial & 3.70 & .50 & 6 \\
\hline
\end{tabular}




\begin{tabular}{llll}
\hline Linguistic & 3.66 & .56 & 7 \\
Third Year & & & \\
Logical & 4.15 & .45 & 1 \\
Intrapersonal & 4.12 & .38 & 2 \\
Musical & 4.07 & .48 & 3 \\
Linguistic & 4.02 & .46 & 4 \\
Interpersonal & 3.90 & .44 & 5 \\
Spatial & 3.89 & .42 & 6 \\
Bodily & 3.89 & .47 & 7 \\
Fourth Year & & & \\
Intrapersonal & 4.06 & .50 & 1 \\
Logical & 4.01 & .56 & 2 \\
Musical & 4.00 & .54 & 3 \\
Linguistic & 3.92 & .55 & 4 \\
Interpersonal & 3.90 & .54 & 5 \\
Spatial & 3.82 & .46 & 6 \\
Bodily & 3.80 & .53 & 7 \\
\hline
\end{tabular}

Table 2 shows the dominant multiple intelligences of education students when taken as a whole. It shows that Interpersonal Intelligence is the most dominant $(\mathrm{m}=4.0743, \mathrm{SD}=.46629)$, followed by Logical $(\mathrm{m}=4.0419, \mathrm{SD}=.53241)$ and their least dominant intelligence is Bodily $(\mathrm{m}=3.8375$, $\mathrm{SD}=.51180$ ).

The dominant multiple intelligences of education students when they are grouped according to their year levelshows that the most dominant intelligence of $2^{\text {nd }}$ year students is Interpersonal $(\mathrm{m}=4.0944, \mathrm{SD}=.57750)$, and their least dominant intelligence is Linguistic $(\mathrm{m}=3.6560, \mathrm{SD}=.56279)$. For $3^{\text {rd }}$ year education students, the result shows that their most dominant intelligence is Logical $(\mathrm{m}=4.1529, \mathrm{SD}=.44743)$, and their least dominant intelligence is Bodily $(\mathrm{m}=3.8905, \mathrm{SD}=.47180)$. For the $4^{\text {th }}$ year education students, their dominant intelligence is Intrapersonal $(\mathrm{m}=4.0627$, $\mathrm{SD}=.49965)$, followed by Logical $(\mathrm{m}=4.0179$, $\mathrm{SD}=.55539)$, then Musical $(\mathrm{m}=4.0000, \mathrm{SD}=.53541)$ and their least dominant intelligence is Bodily $(\mathrm{m}=3.8094, \mathrm{SD}=.52964)$.

The dominant intelligences of education students when grouped according to their sex shows that the dominant intelligence of males is Intrapersonal $(\mathrm{m}=4.1394, \mathrm{SD}=.39260)$, followed by Logical $(\mathrm{m}=4.1014, \mathrm{SD}=.48624)$ and their least dominant intelligence is Bodily $(\mathrm{m}=3.8634, \mathrm{SD}=.48752)$. For the females, their most dominant intelligence is Intrapersonal $(\mathrm{m}=4.0315, \mathrm{SD}=.50616)$ and their least intelligence is Spatial $(\mathrm{m}=3.8157$, $\mathrm{SD}=.44620$ ).

Howard Gardner is best known for this theory which he developed in 1983 and made some revisions in 1991. To Gardner "we are all able to know the world through language, logicalmathematical analysis, spatial representation, musical thinking, the use of the body to solve problems or to make things, an understanding of other individual and an understanding of ourselves". Gardners continues "Where individuals differ in the strength of these intelligences - the scalled profile on intelligences - and in the ways in which such intelligences are invoked and combined to carry out different tasks, solve diverse problems and progress in various domains" (Gardner, 1993).

Interpersonal intelligence as type of learning preference has the ability to relate to others. They are also known as "People Smart' (Armstrong 2000). They can easily understand and interacts well with others. They are very friendly, sociable and likeable in nature. They are good in tasks and activities which entail group activities, seminars and dialogues. Hence, learning may be well communicated through tasks and activities.

Intrapersonal intelligence considers learners who have self-awareness and the ability to deal with change in the workplace. Their capacity towards self-awareness labels them as "Self-Smart" (Armstrong, 2000). They have the capability to understand themselves and they are aware of how to have a good relationship with others and the world because of their personal cognizance. This type of learning preference is often called emotional intelligence. They exhibit manifestations which have personal objectivity which they can process the changing personal thoughts, beliefs and behavior in relation to their situation. They may appear to be difficult to teach since they tend to focus on themselves. But much can be achieved through tasks that entails self-study and selfdiscovery where the teacher serves as consultant to one's learning.

Table 3 presents the difference in the communication styles when grouped according to level and sex 
Table 3

Difference in the communication styles when grouped according to level and sex

\begin{tabular}{llll}
\hline $\begin{array}{l}\text { Communication Styles } \\
\text { *Sex }\end{array}$ & $\mathrm{N}$ & Sig. & Interpretation \\
\hline Activist & & .130 & No significant \\
Reflector & $\mathrm{n}=179$ & .260 & No significant \\
Theorist & & .736 & No significant \\
Pragmatist & $\mathrm{N}$ & Sig. & No significant \\
\hline Communication Styles & & .727 & Interpretation \\
*Year Level & & .750 & No significant \\
Activist & $\mathrm{n}=179$ & .942 & No Significant \\
Reflector & & .923 & No significant \\
Theorist & & No Significant \\
Pragmatist & & & \\
\hline
\end{tabular}

Note: $* * p<0.05$, there is a significant difference at 0.05 level of confidence

Table 3 shows that there is no significant difference in the communication style of education students when they are grouped according to sex and according to their year level.
Table 4 presents the difference in the multiple intelligences when grouped according to level and sex

\section{Table 4}

Difference in multiple intelligences when grouped according to sex and year level

\begin{tabular}{llll}
\hline Multiple Intelligences*Sex & $\mathrm{N}$ & Sig. & Interpretation \\
\hline Interpersonal & & .525 & No significant \\
Musical & & .564 & No significant \\
Intrapersonal & $\mathrm{n}=179$ & .728 & No significant \\
Bodily & & .382 & No significant \\
Logical & & .460 & No significant \\
Spatial & & .589 & No significant \\
Linguistic & $\mathrm{N}$ & Sig. & No significant \\
\hline Multiple & & .098 & Interpretation \\
Level & & .760 & No significant \\
\hline Interpersonal & & .716 & No significant \\
Musical & & .419 & No significant \\
Intrapersonal & $\mathrm{n}=179$ & .006 & No significant \\
Bodily & & .281 & Significant \\
Logical & & .009 & No significant \\
Spatial & & Significant \\
Linguistic & &
\end{tabular}

Note: $* * \mathrm{p}<0.05$, there is a significant difference at 0.05 level of confidence.

Table 4 shows that there is no significant difference in the multiple intelligences of education students when they are grouped according to sex, but when they are grouped according to their level, there is a significant difference in students' Multiple
Intelligences when it comes to Logical ( $\mathrm{Sig}=.006)$ and to Linguistic (Sig.=009).

Table 5 presents the relationship between type communication styles and multiple intelligences. 


\section{Relationship between type communication styles and multiple intelligences}

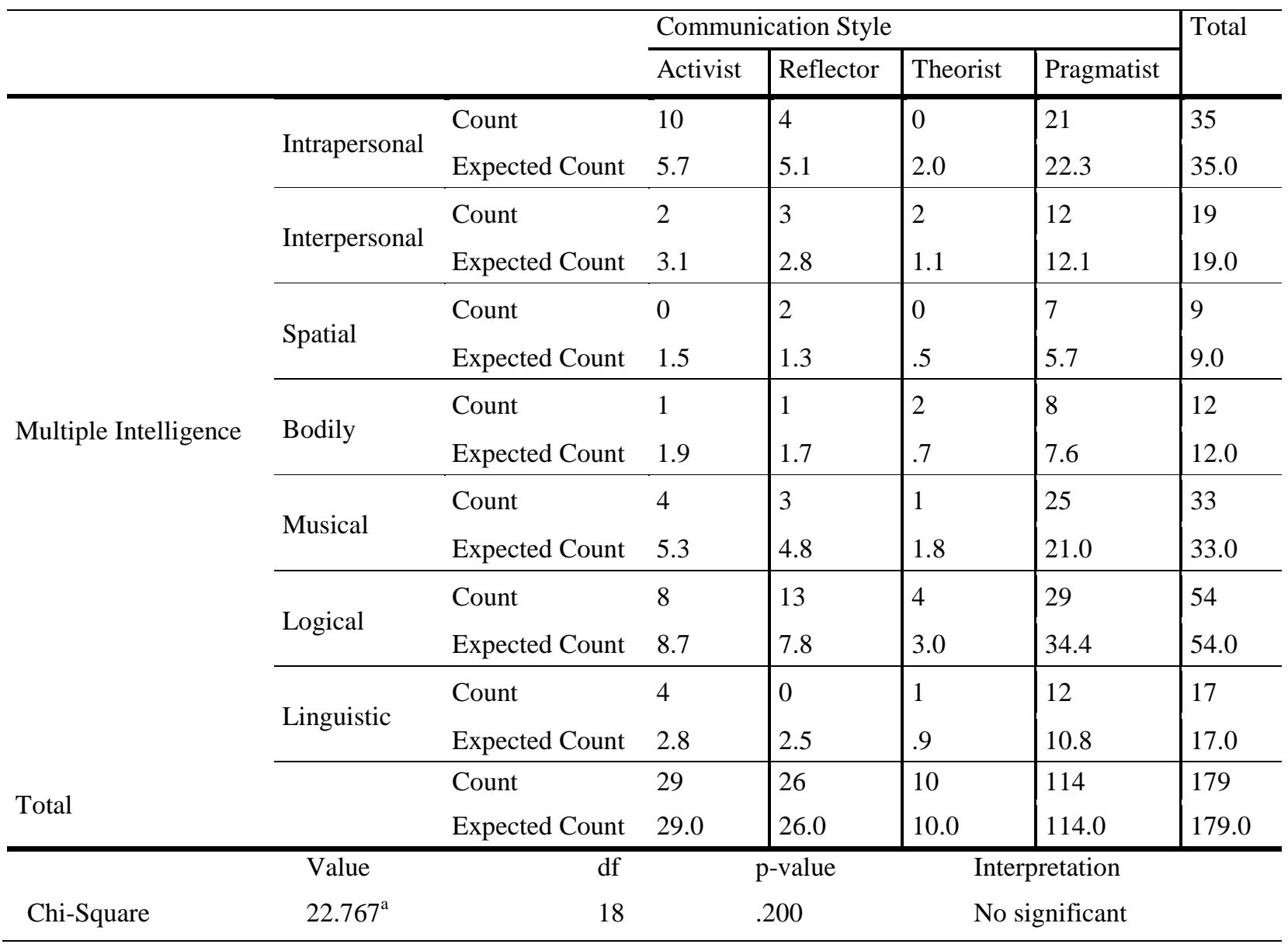

Note: $* * \mathrm{p}<0.05$, there is a significant difference at 0.05 level of confidence.

The table shows the actual and expected count for each intelligence in correspondence to the communication style. Observed count of students with Intrapersonal intelligence who is an Activist $(n=10)$ is higher than the expected count $(n=5.7)$, same with the Pragmatist, observed count $(n=21)$ is lower than the expected count $(n=22.3)$. Also, observed count of students with Intrapersonal intelligence who is a Refelctor $(n=4)$ is lower than the expected count $(n=5.1)$, likewise with the observed count of students who is a Theorist $(n=0)$ and the expected count $(n=2.0)$.

It shows that with $(\mathrm{df}=18$, p-value=.200), there is no significant difference between the observed and expected count, and therefore there can be no enough evidence to claim that students' intelligences are affected by their communication style.

The result of the Chi-Square test [ p-value $=0.200$ ] suggests that there is no significant relationship between communication skills and multiple intelligences of education students. a. 16 cells $(57.1 \%)$ have expected count less than

5 . The minimum expected count is .50 .

\section{Summary of Findings}

The major findings of the study were as follows:

1. The dominant communication styles of the College of Education students when taken as a whole and grouped according to year level and was Pragmatist.

2. The dominant multiple intelligence possessed by the College of Education students when taken as a whole was Interpersonal. According to year level, second year was interpersonal, third year was logical, and fourth year was intrapersonal. As to sex, both male and female possessed intrapersonal intelligence.

3. There was no significant difference that exists between communication styles and personal variables.

4. There was no significant difference that exists between multiple intelligences and personal variables. 


\section{Conclusion}

In view of the findings, the following conclusions were drawn:

1. Majority of the students in the College of Education are pragmatist communicator.

2. Majority of the students in the College of Education possessed interpersonal intelligence.

3. No significant difference exists between communication styles and personal variables.

4. No significant difference exists between multiple intelligences and personal variables.

\section{Recommendations}

In view of the findings and conclusions of the study, the following are recommended:

1. Since majority of College of Education students communicate as pragmatists it will be best to look into the curriculum and the manner of instruction that the college offers. The link between what is learned in the classroom with its application to the present context must be clearly communicated. Motivation for classroom topics and activities must see to it that these are applicable to the present necessities. New ideas, theories and techniques introduced in the teaching process should convey relevancy and applicability to the exigencies of the present. Using models and examples of best practices may best arouse their interest to learn and to try if these work in practice. Though we may consider lecture and theories to be indispensable in the learning process, with pragmatists students there is a need to reduce their discussions and rather highlight their practical advantage.

With the demand for effective learning through a differentiated instruction and after identifying the communication style of majority of the College of Education students, the need for the administration and faculty of the college to invest on training in understanding the different communication and learning styles of students in order to design the curriculum and revisit their approaches and teaching strategies with consideration to these styles.

2. One cannot give what one doesn't have. Since majority of the Education students are interpersonal intelligent, the administration of the College of Education must make further effort to develop this intelligence among its faculty members as catalysts of learning. The faculty members need to learn how to be "Person Smart" by engaging in personality development processes that would enhance their interrelational skills in order to be responsive to the learning styles of students.

The outcome of this research likewise demands that the college re-examine the approaches to teaching of its faculty. A survey may be conducted regarding this matter as basis for faculty re-training.

3. Other researchers are encouraged to conduct another study to prove or disprove the result of the present study.

\section{References}

1. Armstrong, T. (2000) Multiple Intelligences in the Classroom, $2^{\text {nd }}$ ed. USA: Thomas Amrmstrong Inc.

2. Armstrong, T. (2018) Multiple Intelligences in the Classroom, $4^{\text {th }}$ ed. Retrieved on March 6 , 2019 from http://www.ascd.org/publications/books/11803 5/chapters/The-Foundations-of-MI-

Theory.aspx

3. Borek, J. (2003)Inclusion and Multiple Intelligences: Creating a Student-Centered Curriculum. The Quarterly, vol. 25, no. 4. Retrieved on November 12, 2018 from https://archive.nwp.org/cs/public/download/nw p_file/951/Inclusion.pdf?x-r=pcfile_d

4. Fashiku, C. (2017) Effective Communication: Any Role in Classroom Teaching - Learning Process in Nigerian Schools. Bulgarian Journal of Science and Education Policy (BJSEP), Volume 11, Number 1. Retrieved on September 8, 2018 from http://bjsep.org/getfile.php?id=237

5. Gardner, H. (1993) Multiple Intelligences: The Theory in Practice. New York: Basic Books, Inc.

6. Honey, P. and Mumford, A. (2000). The Learning Styles Helper's Guide. Maidenhead: Peter Honey Publications Ltd.

7. Roswell, J. (N.A.) Learning Styles. The Open University. Retrieved on December 8, 2018 fromhttps://www.open.edu/openlearn/ocw/plu ginfile.php/629607/mod_resource/content/1/t1 75_4_3.pdf

8. Silver, F, (2018) Why Is It Important for Teachers to Have Good Communication Skills? Retrieved on November 23, 2018 from http://work.chron.com/important-teachersgood-communication-skills 10512.html

9. Weaver R. and Hybel S. (2001) Communicating Effectively. USA: McGraw Hill Co. 